\title{
Demineralized Dentine Material Membrane As Barrier Mem- brane for Bone Regeneration
}

\author{
Pratiwi Soesilawati ${ }^{1 *}$; Yuliati Yuliati 1; Agnes Paramitha Nastiti ${ }^{2}$; Noor Hayaty Abu Kasim ${ }^{3}$ \\ 1 Department of Oral Biology, Faculty of Dental Medicine, Universitas Airlangga, Surabaya 60132, Indonesia \\ 2 Undergraduate Student, Faculty of Dental Medicine, Universitas Airlangga, Surabaya 60132, Indonesia. \\ 3 Visiting Professor, Faculty of Dental Medicine, Universitas Airlangga, Surabaya 60132, Indonesia. \\ * Correspondence: pratiwi-s@fkg.unair.ac.id; Tel.: +62 315030255
}

\begin{abstract}
Mandibular critical size defect (CSD) due to pathological conditions, trauma, and congenital disease can not heal spontaneously and predominantly filled with fibrous tissue. Therefore, a Guided Bone Regeneration (GBR) combined with bone grafting can be performed. The researchers considered using Demineralized Dentin Material Membrane (DDMM) from bovine dentine as an alternative GBR. This study aimed to determine the amount of fibroblast and collagen density after DDMM and bone graft implantation on CSD. Thirty-six Rattus norvegicus rats were used as samples. Mandibular bone defect 5x5 mm was made, then filled with bone graft and covered with Bovine Pericardium Collagen Membrane (BPCM) in the control group and DDMM in the treatment group. Six samples were sacrificed on 7, 14, and 21 days post-surgical for histology examination. There were no significant differences in the amount of fibroblast and collagen density ( $\mathrm{p}$-value $>$ $0,05)$. The amount of fibroblast is lower and the collagen density is higher in treatment group. DDMM has microporosity to prevent connective tissue ingrowth and dentine tubules to allow growth factors release. DDMM and bone graft implantation can reduce the amount of fibroblasts and increase collagen density of CSD which potentially being used as a CSD alternative treatment for bone regeneration.
\end{abstract}

Keywords: GBR, bone graft, DDMM, fibroblast, collagen fiber.

\section{Introduction}

Mandibular bone damage due to pathological conditions (cysts, tumors, osteomyelitis, periodontal disease, and infections), trauma, and congenital disease create large bone defect or critical size defect (CSD) [1]. The reconstruction of CSD is a significant problem for Oral and Maxillofacial Surgeons because it will not heal spontaneously without intervention. It can regenerate $>10 \%$ of the lost bone during the patient's lifetime [2]. CSD heals predominantly with fibrous tissue, not bone because there are not enough bone-forming cells for bone regeneration. Therefore a guided bone regeneration (GBR) procedure can be performed $[3,4]$.

Guided Bone Regeneration (GBR) is a mechanical barrier membrane placement to protect blood clots and isolate the bone defect from the surrounding connective tissue, thus providing bone-forming cells for bone regeneration [5]. There is the non-resorbable and resorbable membrane. The non-resorbable GBR membrane such as polytetrafluoroethylene (PTFE), expanded polytetrafluoroethylene (e-PTFE), titanium (Ti), and titanium-reinforced PTFE (Ti-PTFE) have been widely used and are commercial. Based on the material, the resorbable GBR membrane can be derived from synthetic materials such as Poly-Lactic Acid (PLA) and Poly-Glycolic Acid (PGA) natural materials such as bovine atau porcine [6]. In resorbable membranes, which tend to be less rigid, the combination of bone graft administration can prevent the membrane from collapsing and maintaining defect space $[7,8]$. 
Bone graft material can be derived from humans (autogenous, isograft, and allograft), other species such as bovine, porcine, equine, coralline, and algae (xenograft), or synthetic materials (alloplastic) [9]. The type of bone graft widely used in bone reconstruction in orthopedics and oral surgery is hydroxyapatite (HA). It is the main bone component (55-56\%) and teeth, containing growth factors anti-infective. The microstructure resembles human bone (biomimetic). Bone regeneration in GBR and bone grafting procedures can be achieved through different mechanisms, including osteoinduction, osteoconduction, and osteogenesis [9-11].

Dentin is a mineralized connective tissue with an organic collagen matrix that contains bone morphogenetic proteins (BMP), platelet-derived growth factor (PDGF), fibroblast growth factor -2 (FGF-2), transforming growth factor-beta 1 (TGF- $\beta 1$ ), and insulin-like growth factor-1 (IGF-1), and IGF-2. However, the amount is lower than bone. Human bone, human dentine, and bovine dentin have similar chemical compositions containing $70 \%$ hydroxyapatite, $20 \%$ organic matrix, and $10 \%$ water [12-15]. Based on the study, the researchers considered bovine dentin as an alternative material in bone regeneration, namely Demineralized Dentin Material Membrane (DDMM), which acts as osteoconduction and osteoinduction.

Collagen is a composition of the organic matrix of bones. In bone, collagen is synthesized by osteoblasts, whereas in connective tissue, collagen is synthesized by fibroblasts [16]. Bone has $95 \%$ collagen type 1 from $80 \%$ protein, which plays a role in maintaining the extracellular matrix's stability for mineral deposition and binding with other macromolecules. Collagen type 1 has a "hole zone" that can promote calcium HA crystals' deposition between the collagen fibers to provide bone strength and density [17-19]. The bundle of irregular collagen fibers and osteocytes forms woven bone, which is then replaced in the remodeling phase by lamellar bone with better mechanical strength [20]. The bone defect healing can result in fibrous tissue formation due to the invasion of fibroblasts into the defect area because the migration rate of fibroblasts is higher than osteoblast. The formation of mature fibrous tissue leads to undesirable situations such as non-union encapsulation. In bone healing, the concept of GBR membrane implantation can prevent these problems [21].

The purpose of this research was to determine the amount of fibroblast and collagen fiber density after DDMM and bone graft implantation on CSD on days 7, 14, and 21 post-implantation procedure.

\section{Materials and Methods}

This research is Post Test Only Control Group Design. The observation of fibroblast and collagen fiber density in rat's mandibular critical bone defect histologically after implantation of BPCM and bone graft (control group) and DDMM and bone graft (treatment group) on day 7,14, and 21. BPCM using Jason membrane, a commercial product, and DDMM processing was performed at Tissue Bank/Center for Biomaterial and Stem Cell, Dr. Soetomo General Hospital, Surabaya.

Each group contains 18 Wistar rats (Rattus norvegicus) age 2-3 months, bodyweight 250-300 g, and healthy condition adapted in cages for seven days to adjust to the new environment. The rats were anesthetized with ketamine $\mathrm{HCl} 20 \mathrm{mg} / \mathrm{kg}$ body weight intramuscularly in the femoral region. The $5 \times 5 \mathrm{~mm}$ defect was made in the mandible using wheel bur and irrigated with $\mathrm{NaCl} 0.9 \%$ during defect making. The defect was filled with HA bone graft, then covered with GBR membrane, immersed in physiological fluids for several minutes. The wound area was sutured using silk thread 3.0. On 7, 14, and 21 days post-operation, six animals in each group were euthanized. Tissue samples were fixed in formaline solution, then decalcified in 10\% EDTA solution for six weeks. Tissue samples were processed and embedded in a paraffin block, then cut to a thickness of $3 \mu \mathrm{m}$ and placed in a glass object for Hematoxylin Eosin (HE) staining . Each slide was counted the number of fibroblasts and collagen density using a microscope with a magnification of 400x. The histopathology (HPA) of fibroblasts is the nucleus appears oval, and the cyto- 
plasm is homogeneous and basophilic. Meanwhile, collagen fibers stained pink [21]. In this study, the experimental protocols were approved by the Health Research Ethical Clearance Commission Universitas Airlangga Faculty of Dental Medicine Number 339/HRECC.FODM/VII/2020.

The result was analyzed using a normality test. As data were normally distributed $(p>0,05)$, an Independent T-Test was used to compare the amount of fibroblast and collagen density in the control and treatment groups. The amount of fibroblast and collagen fiber density shows significantly different if $\mathrm{p}<0.05$.

\section{Results}

Fibroblast and collagen density histomorphometry was performed in both sample groups. The amount of fibroblast and collagen density in the control and treatment group on 7,14 , and 21 days post-operation were not significantly different $(p>0,05)$. The histomorphometry data is shown in Table 1, and the histopathology feature is shown in Figure 1 .

Table 1. The amount of fibroblast and collagen fiber density on 7, 14, and 21 days post-implantation.

\begin{tabular}{|c|c|c|c|c|}
\hline \multirow[b]{2}{*}{ Variable } & \multirow[b]{2}{*}{ Day } & \multicolumn{2}{|c|}{ Mean \pm SD } & \multirow[b]{2}{*}{ P-value } \\
\hline & & $\begin{array}{c}\text { Control group } \\
\text { (BPCM+bone graft) }\end{array}$ & $\begin{array}{c}\text { Treatment group } \\
\text { (DDMM+ bone graft) }\end{array}$ & \\
\hline \multirow{3}{*}{ Fibroblast } & $7^{\text {th }}$ & $30 \pm 2,85$ & $29 \pm 6,36$ & .820 \\
\hline & $14^{\text {th }}$ & $26 \pm 4,92$ & $25 \pm 3,16$ & .734 \\
\hline & $21^{\text {st }}$ & $22 \pm 1,6$ & $18 \pm 6,49$ & .250 \\
\hline \multirow{3}{*}{ Collagen fiber } & $7^{\text {th }}$ & $7 \pm 1,33$ & $8 \pm 2,61$ & .501 \\
\hline & $14^{\text {th }}$ & $13 \pm 1,89$ & $15 \pm 1,89$ & .098 \\
\hline & $21^{\text {st }}$ & $10 \pm 2,22$ & $10 \pm 3,34$ & 1.000 \\
\hline
\end{tabular}

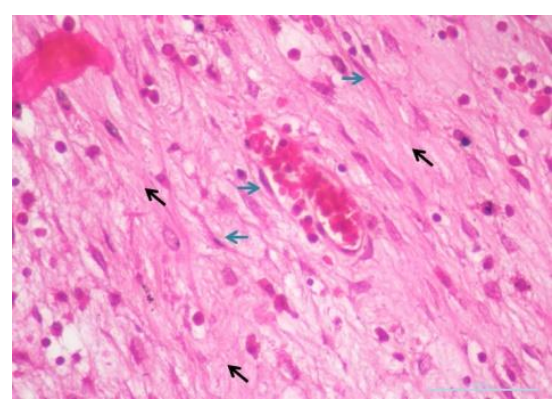

(a)

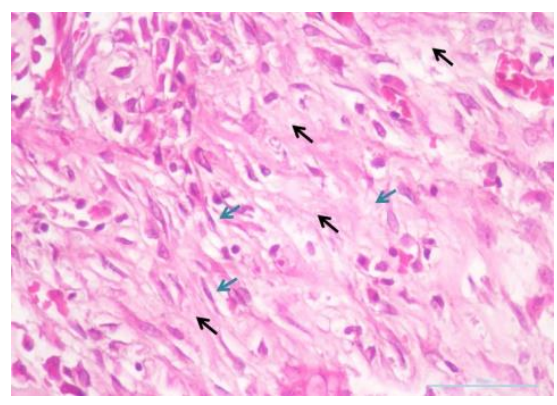

(d)

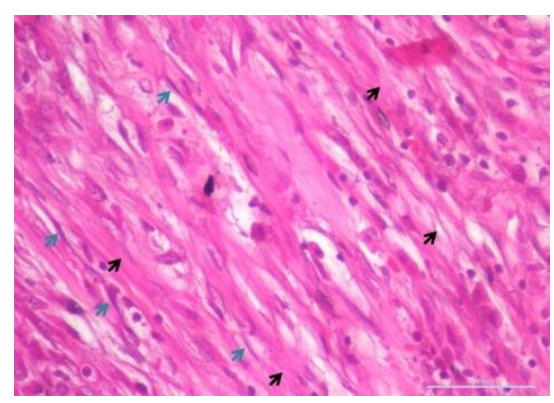

(b)

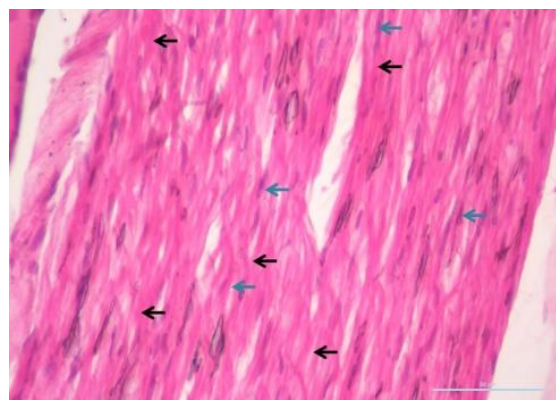

(e)

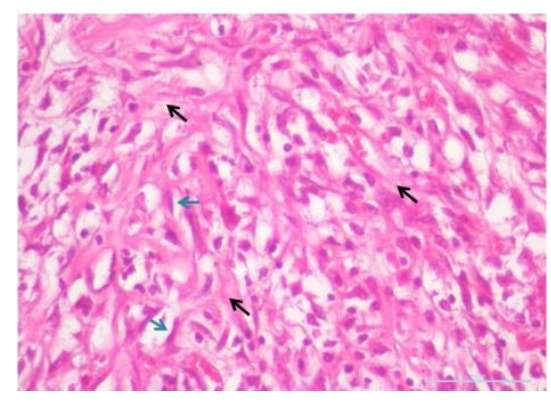

(c)

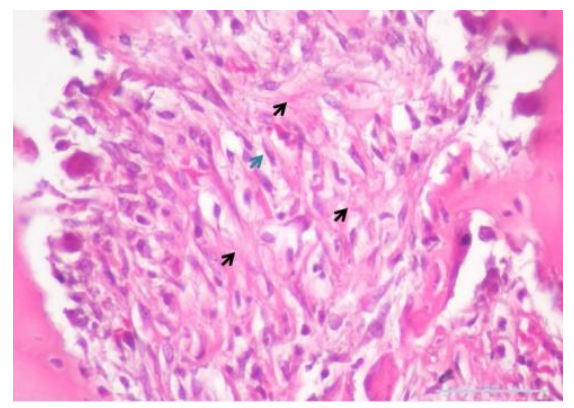

(f) 
Figure 2. Histopathology (HPA) of fibroblast (blue arrow) and collagen fiber (black arrow) on 7, 14, and 21 days (left to right) in mandibular bone defect post-implantation of bone graft combine with (a) ,(b), (c) BPCM and (d) ,(e), (f) DDMM (HE; 400x).

\section{Discussion}

Bone defects undergo healing through four phases there are hemostasis, inflammation, proliferation, and remodeling. In the first 24 hours after the defect is formed, thrombin was released, caused by the blood vessel's rupture under the periosteum. It stimulates the formation of blood clots by platelets. Tissue hypoxia caused by blood vessel damage promote platelet to release IL-1, IL-6, TNF- $\alpha$, PDGF and TGF- $\beta$ to recruit neutrophil and monocyte [22]. IL-1 and IL-6 peak 24 hours post-injury and starts undetectable 72 hours post-injury. In the early inflammatory phase, neutrophil differentiates into PMN to remove pathogens, tissue debris, and thrombus. Neutrophil also release IL-1, TNF- $\alpha$, and MIP-1 to monocyte differentiation into macrophage [22]. Macrophages will phagocyte necrotic cells at the bone ends, bacteria, and secrete inflammatory cytokines and growth factors such as BMP-2, BMP-5, BMP-7, b-FGF, TGF- $\beta$, PDGF, and IGF, which are responsible for migration, recruitment, proliferation, and differentiation of MSC into angioblast, chondroblasts, fibroblasts, and osteoblasts [23]. VEGF, PDGF, and FGF as angiogenic factors secreted by macrophages can also stimulate MSC differentiation into endothelial cells for angiogenesis [24].

On the $7^{\text {th }}$ day post-injury, the early phase of the proliferation phase is characterized by the differentiation of MSCs into fibroblasts and osteoblasts. The inflammatory cells will secrete IL-1 $\beta$, PDGF, and FGF to stimulate fibroblast proliferation, while fibroblast migration to the wound area is stimulated by TGF- $\beta[25,26]$. Implantation of osteoconductive biomaterials can be used as a scaffold or medium to create a suitable atmosphere for adhesion, proliferation, and differentiation of MSCs to osteoblasts as collagen producers [27]. The peak amount of fibroblast and collagen on day $14^{\text {th }}$ is the critical period of the proliferation phase. Day $21^{\text {st }}$ post-injury reduces fibroblast and collagen density because the remodeling phase has just started. Osteoclasts secrete hydrogen ions and the enzyme lysosome cathepsin K, which degrades all components of the bone matrix, including collagen, to form a Haversian lacuna basin, which will be filled with new bone matrix by osteoblasts in the formation stage in the remodeling phase $[28,29]$. Collagenase (MMP-8 and MMP-13), produced by osteoclast, also degrades collagen fiber causes decreasing collagen density on the $21^{\text {st }}$ day [30].

Synthetic bone graft (alloplastic) has osteoconductive properties that can scaffold for adhesion and development of osteogenic progenitor cells or MSC and new blood vessels [9,31,32]. The increase in the number of MSCs which proliferate and differentiate into preosteoblasts causes collagen synthesis to increase. In the study of Vidyahayati et al. (2016), bone graft HA is known to increase the number of osteoblasts during bone formation on the 14th day. Bone graft particles with a porosity $>50 \%$ of the graft volume and pore sizes of 200-800 show optimal bone development as they allow for osteoblast migration, adhesion, and proliferation [9]. The particle size of the bone graft coralline HA used in this study was estimated to have porosity $>70 \%$ and pore size of $500-600 \mu \mathrm{m}$ so that osteoblast proliferation was good and collagen production increased [34].

The number of fibroblasts and collagen density at days 7, 14 and 21 in both groups showed no significant difference. It can be due to the size of the porosity of DDMM and BPCM not much different. DDMM has a porosity of $3.4 \mu \mathrm{m}$, while BPCM has a porosity of $3.9 \mu \mathrm{m}$. Microporosity $(<1-5 \mu \mathrm{m})$ is beneficial in vivo because it can stimulate bone regeneration [35]. Larger pore size will allow soft tissue-forming cells to grow faster, thus inhibiting infiltration and osteogenic cell activity [36]. The higher porosity and larger pore size may be beneficial in vivo because it can stimulate bone regeneration [35]. In the cytotoxicity test (MTT assay), DDMM is known to have the potential to increase the number of MC3T3-E1 osteoblasts, which are producers of collagen in bone [37]. The demineralization process in making DDMM is known to maintain the content of type 1 collagen. BMP-2 released by DDMM increases the differentiation of MSCs into 
osteoblasts so that the amount of collagen secreted is increasing [5]. The membrane thickness also affects the space-making ability, affecting the growth of soft tissue to the defect area. The thickness of DDMM was $300 \mu \mathrm{m}$ and BPCM $150 \mu \mathrm{m}$, which made DDMM better to prevent an invasion of fibroblasts into the defect area [35].

\section{Conclusions}

DDMM and bone graft implantation can reduce the amount of fibroblasts and increase collagen density of CSD which potentially being used as a CSD alternative treatment for bone regeneration.

Author Contributions: Conceptualization, P.S.; methodology, P.S..; software, P.S.; validation, P.S, Y. and A.P.N.; formal analysis, P.S.; investigation, A.P.N.; resources, Y.; data curation, N.H.A.K.; writing-original draft preparation, A.P.N.; writing-review and editing, A.P.N.; visualization, N.H.A.K.; supervision, P.S..; project administration, Y.; funding acquisition, P.S. All authors have read and agreed to the published version of the manuscript.

Funding: The study was financially supported by the Ministry of Research, Technology and Higher Education, the Republic of Indonesia, Grant no. 616/UN3.14/PT/2020.

Data Availability Statement: The datasets used and/or analyzed during the present study are available from the corresponding author on reasonable request.

Acknowledgments: Not applicable.

Conflicts of Interest: The authors declare no conflict of interest.

\section{References}

1. Shah, S.R.; Young, S.; Goldman, J.L.; Jansen, J.A.; Wong, M.E.; Mikos, A.G. A composite critical-size rabbit mandibular defect for evaluation of craniofacial tissue regeneration. Nat. Protoc. 2016, 11, 1989-2009, doi:10.1038/nprot.2016.122.

2. Brierly, G.I.; Tredinnick, S.; Lynham, A.; Woodruff, M.A. Critical Sized Mandibular Defect Regeneration in Preclinical In Vivo Models. Curr. Mol. Biol. Reports 2016, 2, 83-89, doi:10.1007/s40610-016-0036-4.

3. Subagio, E.W.; Kamadjaja, D.B.; Afikaningtyas, D.; Abidin, Z.Z.; Soesilowati, P.; Pramono, C. Early healing phase in rat's calvarial critical-size defect after implantation of bovine cortical membrane. Asian J. Microbiol. Biotechnol. Environ. Sci. 2018, 20, S113-S116.

4. Kamadjaja, D.B.; Harijadi, A.; Soesilawati, P.; Wahyuni, E.; Maulidah, N.; Fauzi, A.; Rah Ayu, F.; Simanjuntak, R.; Soesanto, R.; Asmara, D.; et al. Demineralized Freeze-Dried Bovine Cortical Bone: Its Potential for Guided Bone Regeneration Membrane. Int. J. Dent. 2017, 2017, 1-10, doi:10.1155/2017/5149675.

5. Turri, A.; Elgali, I.; Vazirisani, F.; Johansson, A.; Emanuelsson, L.; Dahlin, C.; Thomsen, P.; Omar, O. Guided bone regeneration is promoted by the molecular events in the membrane compartment. Biomaterials 2016, 84, 167-183, doi:10.1016/j.biomaterials.2016.01.034.

6. Dimitriou, R.; Mataliotakis, G.I.; Calori, G.M.; Giannoudis, P. V. The role of barrier membranes for guided bone regeneration and restoration of large bone defects: Current experimental and clinical evidence. BMC Med. 2012, 10, 1-24.

7. Liu, J.; Kerns, D.G. Mechanisms of Guided Bone Regeneration: A Review. Open Dent. J. 2014, 8, 56-65, doi:10.2174/1874210601408010056.

8. Elgali, I.; Omar, O.; Dahlin, C.; Thomsen, P. Guided bone regeneration: materials and biological mechanisms revisited. Eur. J. Oral Sci. 2017, 125, 315-337, doi:10.1111/eos.12364.

9. Titsinides, S.; Agrogiannis, G.; Karatzas, T. Bone grafting materials in dentoalveolar reconstruction: A comprehensive review. Jpn. Dent. Sci. Rev. 2019, 55, 26-32, doi:10.1016/j.jdsr.2018.09.003.

10. Ardhiyanto, H.B. Peran hidroksiapatit sebagai bone graft dalam proses penyembuhan tulang. Stomatognatik J. Kedokt. Gigi 2011, 8, 6-9.

11. Ebrahimi, M. Bone grafting substitutes in dentistry: general criteria for proper selection and successful application. IOSR J. 
Dent. Med. Sci. 2017, 16, 75-79, doi:10.9790/0853-1604037579.

12. Um, I.W. Extracted Tooth : Can it be A Bone Graft Substitute? 2017, 4, 1-3, doi:10.19080/ADOH.2017.04.555627.

13. Gao, X.; Qin, W.; Wang, P.; Wang, L.; Weir, M.D.; Reynolds, M.A.; Zhao, L.; Lin, Z.; Xu, H.H.K. Nano-structured demineralized human dentin matrix to enhance bone and dental repair and regeneration. Appl. Sci. 2019, 9, 1-14, doi:https://doi.org/10.3390/app9051013.

14. Sari, D.S.; Maduratna, E.; Ferdiansyah, F.; Sudiana, I.K.; Rantam, F.A. Cytotoxicity test and characteristics of demineralized dentin matrix scaffolds in adipose-derived mesenchymal stem cells of rats. Dent. J. (Majalah Kedokt. Gigi) 2018, 51, 194-199, doi:10.20473/j.djmkg.v51.i4.p194-199.

15. Putri, I.L.; Rachman, A.; Soesilawati, P.; Hakim, L.; Rantam, F.A.; Perdanakusuma, D.S. Addition of adipose derived stem cell to beta tricalcium phosphate and human cancellous bone for craniofacial bone tissue engineering: An in vitro study. Malaysian J. Med. Heal. Sci. 2020, 16, 83-86.

16. Sbricoli, L.; Guazzo, R.; Annunziata, M.; Gobbato, L.; Bressan, E.; Nastri, L. Selection of collagen membranes for bone regeneration: A literature review. Materials (Basel). 2020, 13, 1-16, doi:10.3390/ma13030786.

17. Lieberman, J.R.; Friedlaender, G.E. Bone Regeneration and Repair: Biology and Clinical Applications; Humana Press Inc.: New Jersey, 2005; ISBN 1592598633.

18. Ardhiyanto, H.B. Peran Hidroksiapatit Sebagai Material Bone Graft Dalam Menstimulasi Kepadatan Kolagen Tipe 1 Pada Proses Penyembuhan Tulang. Stomatognatic (J.K.G Unej) 2012, 9, 16-18.

19. Blair, H.C.; Larrouture, Q.C.; Li, Y.; Lin, H.; Beer-Stoltz, D.; Liu, L.; Tuan, R.S.; Robinson, L.J.; Schlesinger, P.H.; Nelson, D.J. Osteoblast differentiation and bone matrix formation in vivo and in vitro. Tissue Eng. - Part B Rev. 2017, 23, 268-280, doi:10.1089/ten.teb.2016.0454.

20. Baron, R. Anatomy and Ultrastructure of Bone - Histogenesis, Growth and Remodeling; MDText.com, Inc., 2019;

21. Soesilawati, P.; Nastiti, A.P.; Alwino, M.; Firdauzy, B.; Yuliati, Y.; Hayaty, N.; Kasim, A.B.U. Regulating The Fibroblast Growth Into Critical Size Mandibular Bone Defect via Demineralized Dentin Material Membrane Implantation. Int. J. Pharm. Res. 2021, 13, 3758-3763, doi:10.31838/ijpr/2021.13.01.537.

22. Baht, G.S.; Vi, L.; Alman, B.A. The Role of the Immune Cells in Fracture Healing. Curr. Osteoporos. Rep. 2018, 16, 138-145, doi:doi: 10.1007/s11914-018-0423-2.

23. Oryan, A.; Monazzah, S.; Bigham-Sadegh, A. Bone injury and fracture healing biology. Biomed. Environ. Sci. 2015, 28, 57-71, doi:doi: 10.3967/bes2015.006.

24. Tal, H. Bone Regeneration; InTech: Kroasia, 2012; ISBN 9789535104872.

25. Sumbayak, E.M. Fibroblas : Struktur dan Peranannya dalam Penyembuhan Luka. J. Kedokt. Meditek 2015, 21 , 1-6.

26. Ismardianita, E.; Elianora, D.; Rosalina, W.; Nofrike, L.; Khairani, V.Y. The effectiveness methanol extract clausena excavate on number of fibroblast and density of collagen fibers after tooth extraction. 2019, 4, 170-175, doi:10.15562/jdmfs.v4i3.996.

27. Herda, E.; Puspitasari, D. Tinjauan peran dan sifat material yang digunakan sebagai scaffold dalam rekayasa jaringan. J. Mater. Kedokt. gigi 2016, 1, 56-63.

28. Marquis, M.; Lord, E.; Bergeron, E.; Drevelle, O.; Park, H.; Cabana, F.; Faucheux, N. Bone cells-biomaterials interactions. Front. Biosci. 2009, 14, 1023-1067.

29. Mahmudati, N. Kajian Biologi Molekuler peran Estrogen/ Fitoestrogen pada Metabolisme Tulang Usia Menopause. Semin. Nas. VIII Pendidik. Biol. 2011, 421-430.

30. Kurzepa, J.; Baran, M.; Watroba, S.; Barud, M.; Babula, D. Collagenases and gelatinases in bone healing. The focus on mandibular fractures. Curr. Issues Pharm. Med. Sci. 2014, 27, 121-126, doi:10.2478/cipms-2014-0029.

31. Almutairi, A.S. A Descriptive Analysis of Patient's Preferences in Bone Graft Therapy in Dentistry. Int. J. Health Sci. (Qassim). 2019, 13, 24-28.

32. McPherson, R.A.; Vickers, P.G.; Slater, G.L. Bone Grafting with Coralline Hydroxyapatite. EC Dent. Sci. 2019, 18, $2413-2423$. 
33. Vidyahayati, I.L.; Dewi, A.H.; Ana, I.D. Pengaruh Substitusi Tulang Dengan Hidroksiapatit (HAp) Terhadap Proses Remodeling Tulang. Media Med. Muda 2016, 1, 157-164.

34. Damien, E.; Revell, P.A. Coralline hydroxyapatite bone graft substitute: A review of experimental studies and biomedical applications. J. Appl. Biomater. Biomech. 2004, 2, 65-73.

35. Pradhitta, R.A. Uji porositas dan morfologi demineralized dentin material membrane sebagai guided bone regeneration; 2019;

36. Rispoli, L.; Fontana, F.; Berreta, M.; Poggio, C.; C., M. Surgery Guidelines for Barrier Membranes in Guided Bone Regeneration (GBR). J. Otolaryngol. Rhinol. 2015, 1.

37. Arrosyad, A.R. Uji Sitotoksisitas Demineralized Dentin Material Membrane Terhadap Kultur Sel Osteoblas MC3T3-E1 Melalui Uji MTT., 2019. 